\title{
UPAYA PENINGKATAN HASIL BELAJAR PERSAMAAN DASAR AKUNTANSI MELALUI METODE KOOPERATIF TIPE NHT DIKELAS X AK 1 SMK NEGERI 7 MEDAN
}

\author{
Romauli Manurung ${ }^{1)^{*}}$ \\ 1) Guru SMK Negeri 7 Medan \\ E-mail: lymanroe@ rocketmail.com
}

\begin{abstract}
Penelitian ini bertujuan untuk mengetahui Peningkatan Hasil Belajar siswa kelas X AK 1 SMK Negeri 7 Medan pada Pembelajaran Persamaan Dasar Akuntansi dengan menggunakan metode kooperatif tipe Numbered Head Together (NHT).Penelitian ini dilaksanakan di SMK Negeri 7 Medan yang dilaksanakan pada bulan September 2015 dengan populasi dan sampel dari penelitian ini adalah kelas X AK 1 di SMK Negeri 7 Medan yang berjumlah 39 orang. Teknik pengumpulan data dari penelitian ini adalah test essay atau uraian yang berbentuk test baku dan observasi. Berdasarkan hasil analisis data diketahui bahwa ada peningkatan hasil belajar siswa pada tiap siklus, dimana pada saat kondisi awal Hasil post test dan ulangan harian tercatat $56,41 \%$ atau 22 orang siswa tuntas dan 17 siswa atau $43,58 \%$ belum tuntas. KKM mata pelajaran Siklus akuntansi kelas X SMK Negeri 7 Medan adalah 70. Keadaan ini mengalami peningkatan pada postes-1 (siklus-1) tercatat 32 siswa (82.05\%) dari 39 siswa kelas X-AK-1 SMK Negeri 7 Medan, hasil belajarnya tuntas, dan kembali meningkat saat postes-2 (siklus-2) dengan hasil yang memuaskan yaitu tercatat, 38 atau 97,43 \% siswa dapat melakukan pencatatan transaksi ke Persamaan Dasar Akuntansi secara benar dan akurat, sehingga secara klasikal kelas tersebut dinyatakan telah tuntas dalam belajar karena telah memenuhi standar minimal $85 \%$ dari keseluruhan siswa yang tuntas belajar secara individual. Berdasarkan hasil deskripsi data penelitian pada kedua siklus tersebut dapat disimpulkan bahwa penerapan metode kooperatif tipe Numbered Head Together (NHT) melalui alur Penelitian Tindakan Kelas (PTK) dapat meningkatkan hasil belajar siswa.
\end{abstract}

Kata Kunci : Penerapan metode kooperatif tipe Numbered Head Together (NHT), Peningkatkan Hasil Belajar . 


\section{PENDAHULUAN}

Pendidikan merupakan salah satu usaha untuk mencerdaskan bangsa dan merupakan kunci pokok untuk mencapai cita-cita suatu bangsa. Pendidikan menduduki masalah yang sangat penting dalam pembangunan karena sasarannya adalah peningkatan sumber daya manusia. Salah satu cara untuk meningkatkan kualitas sumber daya manusia adalah dengan meningkatkan mutu pendidikan sebagai sarana dalam pencerdasan manusia tersebut. Lembaga pendidikan mempunyai peranan yang sangat penting untuk mewujudkan tujuan pendidikan karena pendidikan merupakan proses yang sangat menentukan dalam pencapaian kualitas sumber daya manusia.

Belajar adalah suatu proses pendidikan yang kompleks yang terjadi pada diri setiap orang sepanjang hidupnya. Salah satu pertanda bahwa seseorang itu telah belajar adalah adanya perubahan tingkah laku pada diri orang tersebut yang disebabkan oleh terjadinya perubahan pada tingkat pengetahuan, ketrampilan atau sikap.

Proses Kegiatan belajar mengajar akan berjalan baik apabila ada interaksi antara komponenkomponen yang berhubungan langsung dengan pembelajaran tersebut. Seperti komponen siswa yang berinteraksi dengan komponen guru, metode/Media, peralatan dan lingkungan kelas yang terarah pada pencapaian tujuan pengajaran. Dan sebaliknya komponen guru juga harus berinteraksi dengan komponen lainnya. Dan guru memegang peranan penting dalam interaksi antar komponen tersebut.

Peranan Guru dalam proses pembelajaran sangat berpengaruh besar. Sebab Guru merupakan motivator bagi siswa dalam pembelajaran sehingga kegiatan pembelajaran yang dilaksanakan berjalan dengan baik dan memberikan hasil yang maksimal yaitu adanya perubahan positip dalam diri siswa. Untuk mencapai hasil tersebut, guru harus mampu memilih dan menyesuaikan model dan Mediasi pembelajaran yang tepat dengan materi yang akan disampaikan. Sehingga dengan pembelajaran yang demikian akan menciptakan suasana kelas yang aktif, karena ada interaksi yang positif antara guru dengan siswa dan siswa dengan siswa.

Menurut Slameto (2003), pada dasarnya ada 2 faktor yang menyebabkan rendahnya hasil belajar siswa, yaitu faktor yang berasal dari dalam diri siswa yang disebut dengan faktor internal dan yang berasal dari luar diri siswa
NIAGAWAN Vol 7 No 3 November 2018 disebut dengan faktor eksternal. Faktor internal yang mempengaruhi hasil belajar siswa adalah kemampuan, kesiapan, inteligensi, sikap dan minat. Sedangkan faktor eksternal yaitu lingkungan keluarga, masyarakat dan sekolah. Faktor sekolah meliputi metode/strategi mengajar guru yang kurang tepat, relasi guru dengan siswa, siswa dengan siswa, disiplin sekolah dan kelengkapan fasilitas sekolah.

Mata Diklat Siklus Akuntansi merupakan salah satu mata diklat produktif yang dipelajari di SMK Bisnis Management yang diharapkan dapat meningkatkan pengetahuan, ketrampilan, sikap dan nilai-nilai yang terkandung didalamnya. Seorang guru dituntut harus bisa mentransfer ilmu yang dimilikinya kepada siswa. Dalam Pelaksanaan proses belajar mengajar di dalam kelas, guru harus memperhatikan tingkat kemampuan siswa yang berbeda karena didalam satu kelas terdapat perbedaan kemampuan dalam menangkap ilmu yang diberikan guru, dengan demikian seorang guru harus bisa menentukan alternatif yang harus diambil dalam proses belajar guna tercapainya tujuan pembelajaran yaitu mutu pendidikan yang dihasilkan akan lebih baik dari apa yang telah dihasilkan sebelumnya.

Harapan tersebut belum nampak pada siswa kelas X AK-1 SMK Negeri 7 Medan, karena terbukti dengan rata-rata nilai harian peserta didik, dimana sekitar 47,37 \% atau sebanyak 20 orang dari 39 orang siswa di kelas $\mathrm{X}$ AK-1 tidak tuntas dalam pembelajaran Persamaan Dasar Akuntansi dengan nilai kurang dari 70, Sementara Kriteria Ketuntasan Minimum (KKM) yang ditetapkan untuk mata Diklat tersebut adalah 70. Kemungkinan ini dikarenakan peserta didik kurang mengerti karena ini mata diklat yang baru mereka kenal. Peserta didik merasa kesulitan dalam memahami konsep-konsep materi Siklus Akuntansi. Hal ini akan membuat siswa kurang berminat dan bosan.

Untuk mengatasi permasalahan tersebut, guru perlu mengadakan perbaikan pembelajaran dengan mendesain model pembelajaran sebagai strategi untuk meningkatkan penalaran siswa, guru sebagai pengajar harus mampu menggunakan strategi dan metode pengajaran yang bervariasi sehingga proses belajar mengajar menjadi lebih menarik dan tidak membosankan. Salah satu model pembelajaran yang dapat diterapkan adalah model pembelajaran kooperatif tipe Numbered Head 
Together (NHT). Karena model ini didesain untuk mempengaruhi aktivitas siswa agar lebih aktif dalam proses belajar. Model NHT ini disajikan melalui suatu pembelajaran berkelompok yang terdiri dari 5 sampai 6 orang kelompok siswa. Siswa dikelompok dituntut untuk belajar bersama dan menguasai materi pelajaran yang telah ditetapkan. Dengan penerapan model pembelajaran ini diharapkan dapat meningkatkan aktivitas dan pemahaman siswa dalam pembelajaran yang berdampak pada adanya peningkatan hasil belajar..

\section{TINJAUAN PUSTAKA}

\section{Arti Belajar}

Pengertian belajar secara luas (1994) adalah suatu aktivitas mental/ psikis yang berlangsung interaksi dalam lingkungan yang menghasilkan perubahan dalam pengetahuan, sikap dan keterampilan, Hasan (1994), Suryabrata (1993) menyebutkan sesuatu itu disebut belajar apabila, Belajar itu membawa perubahan (dalam arti behavioral changes, actual maupun potensial). Perubahan itu pada pokoknya adalah didapatnya kecakapan yang baru dan Perubahan itu karena usaha sengaja. Sedangkan secara sederhana pengertian belajar adalah usaha sadar yang dilakukan siswa untuk memperoleh perubahan kearah yang lebih baik.

Rusyan dkk, (1989) mengartikan belajar sebagai usaha memodifikasi atau memperteguh kelakuan melalui pengalaman. Di dalam rumusan tersebut terkandung makna bahwa belajar merupakan suatu proses, suatu kegiatan dan bukan hasil atau tujuan. Belajar bukan hanya mengingat melainkan mengalami. Hasil belajar bukan hanya penguasaan hasil latihan melainkan perubahan kelakuan. Sementara Sujana (1988) berpendapat bahwa belajar adalah suatu proses yang ditandai dengan adanya perubahan pada diri seseorang. Perubahan sebagai hasil dari proses belajar dapat ditunjukkan dalam berbagai bentuk seperti perubahan pengetahuan, pemahaman, sikap dan tingkah laku, keterampilan, kecakapan dan kemampuannya, serta perubahan aspek-aspek lain yang ada pada individu yang belajar.

Menurut Darsono dkk (2000) “ Pembelajaran adalah suatu kegiatan yang dilakukan oleh guru sedemikian rupa sehingga tingkah laku siswa berubah kea rah yang lebih baik ". Perubahan itu pada pokoknya adalah didapatnya kecakapan yang baru dan Perubahan itu karena usaha sengaja. Sedangkan secara
NIAGAWAN Vol 7 No 3 November 2018 sederhana pengertian belajar adalah usaha sadar yang dilakukan siswa untuk memperoleh perubahan kearah yang lebih baik.

\section{Hasil Belajar.}

Hasil belajar adalah tingkat penguasaan yang dicapai oleh siswa dalam mengikuti program belajar mengajar sesuai dengan tujuan yang ingin dicapai, Soedijarto pada Analisis Pendidikan (1981). Fungsinya adalah sebagai alat untuk menilai keberhasilan suatu proses pengajaran, Mursell (1975). Hasil belajar peserta didik dapat dilihat dari ada tidaknya perubahan pada aspek kognitif, afektif dan psikomotorik yang dicapai siswa setelah proses pembelajaran berlangsung.

Pembelajaran dikatakan berhasil apabila hasil pembelajaran dikuasai sebahagian besar siswa. Hasil pembelajaran tersebut dinyatakan dalam bentuk scor atau nilai. Jika persentasi penguasaan materi siswa tinggi maka pembelajaran dikatakan berhasil, tetapi bila persentasi perolehan nilai rendah, maka proses pembelajaran tidak berhasil. Jadi hasil belajar yang dicapai siswa dapat dilihat dari ada tidaknya perubahan tingkah laku siswa yang ditunjukkan dengan nilai melalui test atau ulangan sebagai alat ukurnya.

Hasil Belajar tidak terlepas dari suatu tindakan atau aksi yang kemudian disebut dengan proses. Dan semua orang mengharapkan hasil yang terbaik dari segala usaha yang dilakukannya. Demikan juga dengan pendidikan, Proses pembelajaran yang panjang yang telah dilakukan tentu akan membuahkan hasil. Hasil yang diharapkan berupa adanya perubahan sikap, ketrampilan ataupun pengetahuan bagi siswa. Dan hasil yang didapat tersebut diperoleh melalui suatu proses belajar mengajar.

Djamarah dan Zain (2005) mengklasifikasikan tingkatan keberhasilan yaitu sebagai berikut :

1. Istimewa/Maksimal.

Apabila seluruh bahan pelajaran yang diajarkan itu dapat dikuasai oleh siswa.

2. Baik sekali/Optimal.

Apabila sebagian besar (76\% s.d 99\%) bahan pelajaran yang diajarkan dapat dikuasai oleh siswa.

3. Baik/minimal.

Apabila bahan pelajaran yang diajarkan hanya (60\% s.d 75\%) saja dikuasai oleh siswa

\section{Kurang.}

Apabila bahan pelajaran yang diajarkan kurang dari $60 \%$ dikuasai oleh siswa. 
Dalam kaitan penelitian ini Peneliti menyimpulkan bahwa pembelajaran dikatakan berhasil apabila hasil pembelajaran dikuasai sebahagian besar siswa. Hasil pembelajaran tersebut dinyatakan dalam bentuk scor atau nilai. Jika persentasi penguasaan materi siswa tinggi maka pembelajaran dikatakan berhasil, tetapi bila persentasi perolehan nilai rendah, maka proses pembelajaran tidak berhasil. Jadi hasil belajar yang dicapai siswa dapat dilihat dari ada tidaknya perubahan tingkah laku siswa yang ditunjukkan dengan nilai melalui test atau ulangan sebagai alat ukurnya.

\section{Pengukuran Hasil Belajar.}

Untuk mengetahui sejauh mana siswa menguasai dan memahami materi yang diajarkan guru harus melaksanakan pengukuran keberhasilan dalam mencapai tujuan belajar. Penilaian hasil belajar menekankan pada informasi tentang seberapa jauh siswa telah mencapai kompetensi yang telah ditetapkan. Banyak alat ukur yang dapat digunakan untuk mengukur hasil belajar, diantaranya berupa test atau test hasil belajar.

Test hasil belajar merupakan alat ukur yang disusun secara terencana untuk mengetahui sejauh mana siswa telah menguasai bahan-bahan atau materi yang telah diajarkan. Fungsi utama test hasil belajar di kelas adalah mengukur keberhasilan belajar siswa. Prosedur test dalam mengukur hasil belajar siswa mengandung nilainilai pendidikan yang sangat penting. Test membantu para guru dalam memberikan nilai yang lebih akurat dan lebih dapat dipercaya. Test atau evaluasi hasil belajar juga berfungsi sebagai pemantik munculnya motivasi dalam belajar.

Mengevaluasi keberhasilan rencana dan pelaksanaan kegiatan belajar mengajar merupakan salah satu tugas penting guru yang harus dilaksanakan. Hal itu untuk melihat sejauh mana keberhasilan mengajar guru dan belajar peserta didik secara tepat (valid) dan dapat dipercaya (reliable), kita memerlukan informasi yang didukung oleh data yang objektif dan memadai tentang indikator-indikator perubahan prilaku dan pribadi peserta didik. Karena itu kita biasanya berusaha mengambil cuplikan saja yang diharapkan dapat mencerminkan keseluruhan perubahan prilaku itu, Rusyan dkk (1989).

Menurut Abin Syamsuddin dalam
Rusyan dkk. 1989, beberapa indikator
digambarkan sebagai dan kemungkinan cara

NIAGAWAN Vol 7 No 3 November 2018 mengungkapkannya secara garis besar dapat digambarkan sebagai berikut:

Indikator Penilaian Hasil Belajar

Jenis Hasil Belajar Indikator-Indikator Cara Pengungkapan

\section{A. Kognitif}

-Pengamatan

-Hapalan/ingatan

-Pengertian/pemahaman

-Aplikasi/penggunaan

-Analisis

-Sintesis

-Evaluasi

- dapat menunjukkan, membandingkan, menghubungkan

- dapat menyebutkan dan menunjukkan

- dapat menjelaskan, mendefinisikan dengan kata-kata sendiri

- dapat memberikan contoh, menggunakan dengan tepat, memecahkan masalah

- dapat menguraikan, mengklasifikasikan

- dapat menghubungkan, menyimpulkan, mengenerasikan

- dapat menginterpretasikan, memberikan kritik,memberikan pertimbangan penilaian tugas, test, observasi

B. Afektif

- Penerimaan

- Sambutan

- Penghargaan/apresiasi

- Internalisasi/pendalaman

- Karakterisasi/ Penghayatan

$>$ Bersikap menerima, menyetujui atau sebaliknya

$>$ Bersedia terlibat, memanfaatkan atau sebalinya

$>$ Memandang penting, bernilai, berfaedah indah, harmonis, kagum atau sebaliknya.

$>$ Mengakui, mempercayai, atau sebalikya

> Melembagakan, membiasakan, menjelmakan dalam pribadi dan prilaku sehari-hari.

\section{Psikomotorik}

-Keterampilan

bergerak/bertindak

-Keterampilan ekspresi verbal dan non verbal

- $\quad$ Koordinasi mata, tangan, dan kaki

- Gerak, mimik, ucapan

- Tugas, observasi test, tindakan

- Tugas, observasi, test tindakan 
NIAGAWAN Vol 7 No 3 November 2018

Test hasil belajar dilakukan guru kepada siswanya pada saat proses belajar mengajar, kemudian diolah menjadi nilai. Siswa akan belajar lebih giat bila mereka mengetahui nilai hasil belajarnya. Nilai yang baik dianggap menggambarkan keberhasilan dalam belajar, sebaliknya nilai yang kurang baik dianggap sebagai kegagalan dalam belajar.

Dengan melihat data nilai keberhasilan siswa dalam mencapai tujuan pelajaran, dapatlah diketahui keberhasilan proses belajar mengajar yang telah dilakukan siswa dan guru. Dalam penelitian ini hasil belajar yang dimaksud adalah hasil belajar Siklus Akuntansi pada standar kompetensi Persamaan Dasar Akuntansi.

\section{Pembelajaran Kooperatif}

Pembelajaran kooperatif merupakan pembelajaran yang melibatkan sejumlah siswa atau kelompok kecil. Kelas disusun dalam kelompok yang terdiri dari 4 sampai 6 orang siswa, dengan kemampuan yang heterogen. Heterogen maksudnya kelompok terdiri dari berbagai macam kemampuan siswa, jenis kelamin dan suku. Tujuannya adalah untuk melatih siswa menerima perbedaan dan bekerjasama dengan teman-teman yang berbeda latar belakangnya.

Melalui pembelajaran kooperatif ini siswa diajarkan berbagai keterampilan khusus agar dapat bekerjasama dengan baik, diberi lembar kegiatan berupa pertanyaan-pertanyaan atau tugas yang telah direncanakan untuk mencapai ketuntasan belajar. Menurut Slavin melalui Ibrahim, dkk (2000), konsep sentral yang menjadi karakteristik pembelajaran kooperatif adalah penghargaan kelompok dan pertanggungjawaban individu.

Model pembelajaran kooperatif berdasarkan faham konstruktif. Setiap penyelesaian tugas kelompok, masing-masing anggota harus saling bekerjasama dalam memahami materi pelajaran. Pembelajaran kooperatif dianggap belum selesai jika salah satu diantara anggota kelompok belum menguasai pelajaran. Agar pembelajaran kooperatif mencapai hasil yang maksimal menurut Lie (2004), harus ada 5 unsur yang diterapkan yaitu,

a. Saling Ketergantungan Positif

Keberhasilan kelompok sangat bergantung pada usaha setiap anggotanya. Penilaian dilakukan dengan cara yang unik. Setiap siswa mendapat nilai sendiri dan nilai kelompok. Nilai kelompok dibentuk dari sumbangan setiap anggota kelompok.

b. Tanggungjawab Perseorangan.

Unsur ini merupakan akibat langsung dari unsur yang pertama. Jika tugas dan pola penilaian dibuat menurut prosedur model pembelajaran kooperatif, setiap siswa akan merasa bertanggungjawab untuk melakukan yang terbaik.

c. Interaksi Tatap muka

Setiap kelompok diberi kesempatan untuk bertatap muka dan berdiskusi. Kegiatan interaksi ini akan membentuk sinergi yang menguntungkan semua anggota. Inti dari sinergi adalah menghargai perbedaan, memanfatkan kelebihan dan kekurangan masing-masing.

d. Komunikasi Antar Anggota.

Unsur ini menghendaki waktu khusus bagi kelompok untuk mengevaluasi proses kerja kelompok dan hasil kerjasama mereka agar selajutnya dapat bekerjasama lebih efektif lagi. Pelaksanaan evaluasi tidak perlu dilakukan setiap kali ada kerja kelompok.

e. Evaluasi Proses Kelompok

Pengajar perlu menjadwalkan waktu khusus bagi kelompok untuk mengevaluasi proses kerja kelompok dan hasil kerjasama mereka agar selanjutnya bisa bekerjasama dengan lebih efektif.

Sedangkan unsur-unsur yang harus diterapkan pada pembelajaran Kooperatif menurut Ibrahim dkk (2000) adalah, :

1. Para siswa harus memiliki persepsi bahwa mereka "tenggelam atau berenang bersama".

2. Para siswa harus memiliki tanggungjawab terhadap siswa atau peserta didik lain dalam kelompoknya. Selain tanggungjawab terhadap diri dalam mempelajari materi yang dihadapi.

3. Para siswa harus berpandangan bahwa mereka memiliki tujuan yang sama.

4. Para siswa membagi tugas dan berbagi tanggungjawab antara anggota kelompok.

5. Para siswa diberi evaluasi atau penghargaan yang akan ikut berpengaruh terhadap evaluasi kelompok.

6. Para siswa berbagi kepemimpinan sementara mereka memperoleh keterampilan bekerjasama selama belajar. 
7. Setiap siswa akan dimintai pertanggungjawabannya secara individual materi yang ditangani dalam pembelajaran kooperatif.

Pembelajaran kooperatif memiliki tujuan untuk menciptakan situasi pembelajaran dimana keberhasilan individu ditentukan atau dipengaruhi keberhasilan kelompoknya. Hal ini berbeda dengan kelompok tradisional yang menerapkan sistem kompetisi dimana keberhasilan individu diorientasikan pada gagasan orang lain.

\section{METODE PENELITIAN}

Penelitian ini merupakan Penelitian Tindakan Kelas yang dilakukan secara individual. Artinya peneliti melakukan penelitian sendiri baik dari proses awal sampai akhir kegiatan penelitian yang dilakukan langkah demi langkah di dalam kelas, termasuk biaya penelitian.

Tempat Penelitian Tindakan kelas ini dilakukan di SMK Negeri 7 Medan, yang beralamat di Jl. STM No.12 e. Medan, Kota Medan Sumatera Utara tahun pelajaran 20152016 pada bulan Agustus 2015 hingga Desember 2016. Subjek penelitian adalah siswa kelas XAK-1 SMK Negeri 7 Medan yang berjumlah 39 orang. Penerapan dalam penelitian ini adalah Standar Kompetensi Siklus Akuntansi ,dan Kompetensi Dasar Persamaan Dasar Akuntansi.

Rancangan penelitian menggunakan konsep aksi pada action research oleh Arikunto (2008), yang terdiri dari minimal dua siklus dan masing-masing siklus menggunakan empat komponen tindakan yaitu, Perencanaan, Tindakan, Observasi dan Refleksi dalam suatu konsep yang saling terkait. Detail rancangan penelitian ini mengalami modifikasi sesuai dengan tujuan yang dicapai dijelaskan pada bagan di halaman berikut ini.

Teknik pengumpulan data penelitian ini dilakukan dengan menggunakan tes dan lembar observasi.

1. Test.

Dalam penelitian ini, diberikan test yang bertujuan, untuk mengetahui sumber, kesulitan belajar siswa, agar dapat menentukan langkah-langkah apa yang akan digunakan untuk memperbaiki hasil belajar. Test yang diberikan berbentuk test essay atau uraian yang berbentuk test baku.

2. Observasi
NIAGAWAN Vol 7 No 3 November 2018 Observasi dilakukan untuk mengumpulkan data yang dilakukan secara pengamatan dan mencatat kejadian-kejadian dalam proses belajar mengajar.

Tabel 1 Observasi Aktivitas Siswa

\begin{tabular}{|l|l|l|l|l|l|l|l|l|l|}
\hline \multirow{2}{*}{ No. } & \multirow{2}{*}{ Nama } & \multicolumn{6}{|c|}{ Aspek yang dinilai } & \multirow{2}{*}{ Jumlah } & $\%$ \\
\hline & & 1 & 2 & 3 & 4 & 5 & 6 & & \\
\hline & & & & & & & & & \\
\hline & & & & & & & & & \\
\hline & & & & & & & & & \\
\hline
\end{tabular}

Kunandar (2008)

Aspek yang dinilai antara lain:

1. Memperhatikan Guru menerangkan

2. Membaca materi

3. Mengerjakan soal

4. Berdiskusi

5. Mengajukan Pertanyaan

6. Memberikan jawaban yang tepat dari suatu pertanyaan

\section{Kriteria Penilaian :}
$4=$ Dilakukan Sangat Baik
$3=$ Dilakukan dengan baik
$2=$ Dilakukan cukup baik
$1=$ Dilakukan kurang baik

Indikator keberhasilan penelitian ini adalah dengan melihat adanya peningkatan hasil belajar siswa. Hal ini diukur berdasarkan hasil nilai dan hasil pengamatan selama pembelajaran berlangsung yang dituangkan berdasarkan instrumen yang telah disusun. Apa bila skala penilaian pengamatan aktivitas atau kegiatan siswa yang mendapat kriteria penilaian, Sangat Kurang (0-59), Kurang (60-69), Cukup (70-79), Baik (80-89), dan Sangat Baik (90-100) lebih dari $75 \%$ dari jumlah seluruh siswa. Dan apabila nilai hasil belajar siswa yang melampaui nilai kriteria ketuntasan minimal (KKM) yaitu 70 mencapai $100 \%$ siswa, maka penelitian di anggap telah memperoleh hasil yang diharapkan dan telah memberikan dampak keberhasilannya.

Teknik penyaringan data yaitu dengan mentabulasi instrumen pengamatan yang telah dibuat, baik untuk mengamati kegiatan siswa maupun kegiatan mengajar guru. Data hasil belajar diperoleh dari hasil evaluasi postes yang dilakukan setiap pembelajaran berlangsung.

\section{HASIL DAN PEMBAHASAN}

Keseluruhan peningkatan berbagai kemampuan dan hasil belajar siswa Kelas XAK-1 SMK Negeri 7 Medan dalam proses 
pembelajaran baik dari kondisi awal hingga dilakukan tindakan kelas pada siklus I dan II dapat dilihat sebagai berikut :

Tabel.2 Hasil observasi keseluruhan

\begin{tabular}{|c|c|c|c|c|}
\hline $\begin{array}{l}\mathbf{N} \\
\mathbf{o}\end{array}$ & Aspek yang diamati & $\begin{array}{l}\text { Kondis } \\
\text { i Awal }\end{array}$ & $\begin{array}{l}\text { Peningk } \\
\operatorname{atan}(\%)\end{array}$ & $\begin{array}{c}\text { Siklus I Jlh } \\
\text { Siswa } \\
\text { mengalami } \\
\text { peningkatan }\end{array}$ \\
\hline 1 & $\begin{array}{l}\text { Mendengarkan Guru } \\
\text { menerangkan }\end{array}$ & 30 & $76,92 \%$ & 34 \\
\hline 2 & $\begin{array}{l}\text { Dapat bekerjasama dengan } \\
\text { kelompok }\end{array}$ & 27 & $69,23 \%$ & 32 \\
\hline 3 & $\begin{array}{l}\text { Dapat menjelaskan materi } \\
\text { di kelompoknya }\end{array}$ & 20 & $51,28 \%$ & 28 \\
\hline 4 & Mengajukan pertanyaan & 10 & $25,64 \%$ & 25 \\
\hline 5 & $\begin{array}{l}\text { Dapat memberi jawaban } \\
\text { yang tepat dari suatu } \\
\text { pertanyaan }\end{array}$ & 22 & $56,41 \%$ & 28 \\
\hline 6 & $\begin{array}{l}\text { Dapat mengidentifikasi } \\
\text { transaksi/akun yang } \\
\text { termasuk aktiva, Hutang } \\
\text { dan modal }\end{array}$ & 20 & $51,28 \%$ & 27 \\
\hline 7 & $\begin{array}{l}\text { Dapat mencatat transaksi } \\
\text { ke persamaan Dasar } \\
\text { Akuntansi }\end{array}$ & 20 & $51,28 \%$ & 32 \\
\hline 8 & Hasil Belajar Tuntas & 22 & $56,41 \%$ & 32 \\
\hline
\end{tabular}

\section{PEMBAHASAN}

Pelaksanaan pembelajaran Kooperatif tipe Numbered Head Together (NHT) merupakan suatu pembelajaran kelompok yang memberikan kesempatan kepada siswa untuk saling mempengaruhi, berbagi ide, berpikir bersama dan mempertimbangkan jawaban yang paling tepat. Metode Kooperatif tipe Numbered Head Together adalah suatu pembelajaran kooperatif yang terdiri dari beberapa anggota dalam satu kelompok setiap siswa dalam kelompok diberi nomor. Kelompok mendiskusikan jawaban yang benar dari kuis soal yang diberi guru dan memastikan tiap anggota kelompok dapat mengerjakan dan mengetahui jawabannya. Guru memanggil salah satu nomor siswa dan siswa dengan nomor yang dipanggil melaporkan hasil kerjasamanya, sementara teman-teman yang lain menanggapinya. Kegiatan belajar seperti ini dapat meningkatkan minat, semangat dan hasil belajarnya.. Pelaksanaan pembelajaran Kooperatif tipe Numbered Head Together (NHT) merupakan suatu pembelajaran kelompok yang memberikan kesempatan kepada siswa untuk saling mempengaruhi, berbagi ide, berpikir bersama dan mempertimbangkan jawaban yang paling tepat.

Berdasarkan pengamatan dan hasil observasi Peneliti pada kondisi awal, tindakan siklus 1, 2 dan evaluasi yang dilakukan, terjadi perubahan cara belajar maupun situasi belajar di
NIAGAWAN Vol 7 No 3 November 2018

kelas. Jika sebelumnya pada proses pembelajaran siswa kurang aktif dalam proses belajar mengajar, metode pembelajaran yang digunakan kurang dapat merangsang minat belajar siswiklus bemahaman siswa terhadap

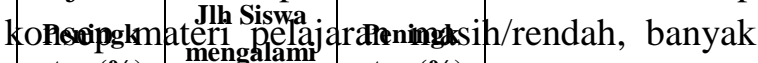

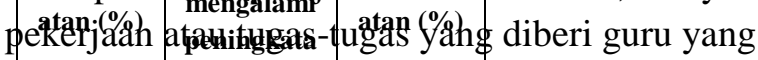
tidak dikerjakdh karena kurang paham dan kưrah7g\% perhälan betajafio serta hasil pembelajaran mata pejajaran Siklus Akuntansi yang masih di hawah KKM, kini sudah dapat \begin{tabular}{|l|l|l}
\hline terattas \% & 34 & $87,17 \%$
\end{tabular} 64,10\%Pembekiajaran 76,92 \%dengan Metode Kooperatif tipe Numbered Head Together $(\mathrm{NHT}) \%$ ternyata lebih ${ }^{31} \%$ menyenangkan dan menumbuhkan rasa kebersamaan, tenang, nyanman dan kondusif 92dio dalam kelas. Hal ini tentu sangat memotivasi keaktifan dan kreatifitas siswa, sehingga merubah sikapnya dalam belajar. Perubahan $93 \%$ ikap belajar siswa itu

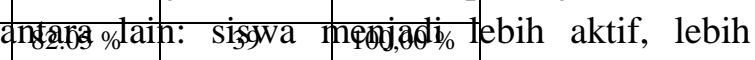
kreatif, bersungguh-sungguh, berani bertanya, berani mengeluarkan ide/ pendapat, lebih hidup, lebih percaya diri, lebih mandiri, bertanggungjawab pada tugas, bebas mengaktualisasikan diri, dan siswa dapat lebih mudah memahami konsep pelajaran yang luas. Dan sebagai hasilnya berbagai kemampuan siswa dan ketuntasan/ hasil belajarpun meningkat.

\section{KESIMPULAN DAN SARAN}

Berdasarkan pembahasan diatas maka dapat ditarik kesimpulan bahwa Penerapan Metode pembelajaran Kooperatif tipe Numbered Head Together (NHT) merupakan suatu pembelajaran kelompok yang memberikan kesempatan kepada siswa untuk saling mempengaruhi, berbagi ide, berpikir bersama dan mempertimbangkan jawaban yang paling tepat. Hasil penerapan Metode pembelajaran Kooperatif tipe Numbered Head Together (NHT) pada proses belajar mengajar sangat efektif meningkatkan ketuntasan/ hasil belajar siswa. Hal ini dapat dilihat dari hasil evaluasi pada kondisi awal hasil belajar para siswa kelas X-AK-1 56,41 \%, dan setelah dilakukan tindakan siklus 1 menjadi 82,05\% dan ketika dilaksanakan siklus 2 meningkat menjadi 100.00 $\%$.

Pembelajaran dengan Metode Kooperatif tipe Numbered Head Together (NHT) ternyata lebih menyenangkan dan menumbuhkan rasa kebersamaan, tenang, 
nyaman dan kondusif di dalam kelas. Hal ini tentu sangat memotivasi keaktifan dan kreatifitas siswa, sehingga dapat merubah sikapnya dalam belajar. Penerapan Pembelajaran dengan Metode Kooperatif tipe Numbered Head Together (NHT) dapat meningkatkan ketuntasan dan hasil belajar siswa. Hasil penelitian ini sangat bermanfaat untuk membantu guru meningkatkan keterampilan menggunakan metode atau pendekatan yang tepat dalam proses pembelajaran.

\section{REFERENSI}

Arikunto, 2008. Dasar-dasar Evaluasi Pendidikan, Jakarta : Bumi Aksara

Arikunto, Suharsimi, dkk. 2007. Penelitian Tindakan Kelas, Jakarta : Bumi Aksara

2008. Dasar-dasar Evaluasi Pendidikan. Jakarta : Bumi Aksara

Christian

(http://re-

searchingines.com/2009/03/10)

Djamarah, S, Zain.2006.Strategi Belajar Mengajar. Jakarta : Rineka Cipta.

Darsono, dkk. 200. Belajar dan Pembelajaran. Semarang : IKIP Semarang Press.

Ibrahim, 2000. Pemelajaran Kooperatif. Jakarta : Grasindo

Khairunnisa. 2008. Penerapan Model Pembelajaran Kooperatif Tipe NHT untuk meningkatkan hasil belajar Ekonomi Siswa Kelas XI SMK Negeri Stabat Tahun Ajaran 2008/2009. Skripsi. FE : Unimed.

Kunandar. 2008. Langkah Mudah Penelitian Tindakan Kelas Sebagai Pengembangan Profesi Guru. Jakarta : Raja Grafindo Persada.

Lie, Anita. 2007. Cooperative Learning, Memperaktekkan Cooperative Learning di Ruang-ruang Kelas. Jakarta : Grasindo.

Jakarta : Grasindo.
NIAGAWAN Vol 7 No 3 November 2018

Nurhadi, 2004. Kurikulum 2004 Pertanyaan dan Jawaban. Malang : Grasindo.

Sanjaya, Wina. 2008. Strategi Pembelajaran Berorientasi Standar Pendidikan, Jakarta : Kencana.

Slameto. 2006. Belajar dan Faktor-Faktor yang mempengaruhinya. Jakarta : Rineka Cipta.

Soemarso. 2004. Akuntansi Suatu Pengantar. Jakarta : Salemba Empat.

Soemantri. 2004. Memahami Akuntansi SMK _Seri A. Bandung : Armico.

Sucipto, dkk. 2006. Siklus Akuntansi Perusahaan Jasa_ 1A. Jakarta : Yudistira.

Sudjana, H. 2001. Metode dan Teknik Pembelajaran Partisipatif. Bandung : Falah Production.

Syaiful, Sagala. 2006. Konsep dan Makna Pembelajaran. Bandung : Alfa Beta.

Trianto. 2007. Model-Model Pembelajaran Inovatif Berorientasi Konstruktivistik. Jakarta : Publisher. 